Vol. 9 (2000): 165-176.

\title{
Pressure to change and resistance against it: consumer perceptions and acceptance of nutritionally modified foods
}

\author{
Hely Tuorila \\ Viikki Food Science, Department of Food Technology, PO Box 27 (Viikki A), FIN -00014 University of \\ Helsinki, Finland, e-mail: hely.tuorila@helsinki.fi
}

\begin{abstract}
Sensory quality and pleasantness are important determinants of food choice. Nutritionally controversial foods, such as those high in fat or sodium, can be consumed excessively due to their sensory attractiveness. The present review addresses sensory and hedonic characteristics in such foods, focusing on Finnish research around the issue. Fat mainly affects the texture of foods, but also modifies flavor and aroma. The replacement of fat by other constituents remains a challenge. Achieving salty taste with substances other than sodium chloride has proven to be unsuccessful, but proper flavoring can improve the pleasantness of reduced-salt foods. The impact of nutritional information and health claims is greater when given for new foods, and to consumers who are concerned about their health. Multi-item verbal instruments have been developed and validated to characterize health and taste orientations among consumers. Identification of sensory and hedonic barriers to the acceptance of 'healthful' alternatives among foods is important, even crucial, for targeting product development and nutritional counseling.
\end{abstract}

Key words: sensory evaluation, consumer preferences, fat, sodium, nutrition information

\section{Introduction}

The dietary guidelines of industrial countries include several common features: the recommendations to reduce intakes of fat and sodium chloride, and to increase those of fiber and other complex carbohydrates (Truswell 1987). The revised Finnish nutritional recommendations emphasize these goals while they also acknowledge the need for tasty foods and enjoyable meals (Valtion ravitsemusneuvottelukunta 1998).

The current food supply in Western countries is abundant, and there are many ways of planning individual diets. Indvidual food choices, in turn, have multiple origins. Some are culturally based, others are personal; some derive from external impulses while others draw upon internal signals (Shepherd 1989). To be nutritionally adequate, the choices should be such that 'healthful' foods would be preferred 
Tuorila, H.Consumer perceptions and acceptance of nutritionally modified foods

over the 'less healthful' foods. However, quite the opposite occurs which can lead to abundant intakes of e.g., high-fat or high-salt foods.

One reason for (from the nutritional viewpoint, anomalous) food choices is that the sensory properties of these foods appeal to consumers. When asked about their reasons to choose a food, people often refer to the taste or liking of a food. For example, among Finnish consumers who were to choose either a chocolate bar or an apple as their afternoon snacks, one-half mentioned taste, liking or pleasure as the reason to choose either one of these options (Roininen and Tuorila 1999). Food choices among Swedish children were best predicted by their liking for a given food, and the rejections were similarly based on expected dislike (Koivisto Hursti 1997). The rated pleasantness and the frequency of use of a food are generally well correlated, with Pearson's $r$ ranging from 0.50 to 0.70 (Lähteenmäki and Tuorila 1994). Thus, the pleasantness of food appears to be an important prerequisite for the intake.

The growing awareness of the importance of sensory factors in food choice, and the scientific evidence on the diet - health associations, have stimulated research into sensory and hedonic aspects of nutritionally modified foods. Several important reviews have been published on the topic, some general (Shepherd 1988), some primarily focusing on fat (Mattes 1996, Mela and Raats 1994) and others on salt (Mattes 1997). The present review addresses such research in Finland, especially at the University of Helsinki where this research theme has been emphasized since the 1980s. The effects of fat and salt on sensory and hedonic responses are discussed, in particular. The interest is in the conditions under which high-fat and high-salt foods vs. their reduced-fat alternatives are accepted, and in consumer characteristics that might facilitate the acceptance. Thus, nutritional problems are examined from the viewpoint of an individual consumer, by examining his or her perceptions, losses and trade-offs.

\section{Two categories of research}

Sensory food research can be divided into two distinct categories: traditional sensory and consumer acceptance (e.g., Lawless and Heymann 1998). Traditional sensory research aims to characterize sensory variations in products which have different compositions or have been processed or stored in a certain way. If the research concerns the reduction of fat or sodium chloride, the sensory effects of reducing these components are identified and quantified. In this case, the assessors have been trained to perform the measurements and the panel, as a whole, is considered an instrument that operates similarly to chemical or physical instruments.

Consumer acceptance research focuses on the interaction between products and consumers, thus setting the sensory quality of a food into a wider perspective. The impact of sensory properties on hedonic (or pleasantness, or liking) responses among individual subjects is measured. Explanations for consumer responses are sought in demographics (age, gender, socioeconomic status) and psychographics (attitudes, expectations, beliefs, experiences). Moreover, consumer acceptance work may focus on contextual factors in food acceptance, such as the effect of product information or the momentary hunger or satiety of an individual. The overall aim is to determine the conditions under which a product is acceptable or preferred in various consumer groups and situations.

\section{Sensory and hedonic effects of fat in foods}

Fat affects all sensory properties, but most of all the texture of foods. Viscosity and creaminess in dairy products, tenderness of meat and bakery products and the fatty mouthfeel and melting properties of confectionery and dairy products 


\section{AGRICULTURAL AND FOOD SCIENCE IN FINLAND}

Vol. 9 (2000): 165-176.

Table 1. Examples of sensory effects of varying fat contents on a range of foods.

\begin{tabular}{|c|c|c|c|c|}
\hline Food & $\begin{array}{l}\text { Fat content } \\
\%\end{array}$ & Source & $\begin{array}{l}\text { Effect of increasing } \\
\text { fat content } \mathrm{t}^{\mathrm{a}}\end{array}$ & Reference \\
\hline Milk & $0-4$ & Dairy & $\begin{array}{l}\text { Greasy mouthfeel } \uparrow \\
\text { Thickness } \uparrow \\
\text { Blueness } \downarrow \\
\text { Transparency } \downarrow\end{array}$ & Tuorila 1986 \\
\hline $\begin{array}{l}\text { Strawberry } \\
\text { yogurt }\end{array}$ & $0-5$ & Dairy & $\begin{array}{l}\text { Sweetness } \uparrow \\
\text { Sourness } \downarrow\end{array}$ & Tuorila et al. 1993 \\
\hline Cheese soup & $3-12$ & Dairy & $\begin{array}{l}\text { Thickness } \uparrow \\
\text { Fatty mouthfeel } \uparrow \\
\text { Cheese and overall odor } \uparrow \\
\text { Saltiness } \uparrow\end{array}$ & Kähkönen et al.1995 \\
\hline Bakery products & $\begin{array}{l}6-13 \\
22-30\end{array}$ & Vegetable & Tenderness $\uparrow$ & $\begin{array}{l}\text { Hogbin and Fulton } \\
1992\end{array}$ \\
\hline Meat patties & $5-30$ & Beef & $\begin{array}{l}\text { Moistness } \uparrow \\
\text { Juiciness } \uparrow \\
\text { Firmness } \downarrow\end{array}$ & Troutt et al. 1992 \\
\hline Confectionery $^{b}$ & $45-75$ & Cocoa & $\begin{array}{l}\text { Viscosity of mass } \uparrow \\
\text { Hardness } \uparrow \\
\text { Adhesiveness } \uparrow \\
\text { Particles in the mouth } \uparrow \\
\text { Sweetness } \downarrow \\
\text { Melting rate in the mouth } \downarrow\end{array}$ & Lawless et al. 1996 \\
\hline
\end{tabular}

a $\uparrow$ attribute intensity increases, $\downarrow$ attribute intensity decreases

b part of cocoa fat was replaced by fat substitutes

are examples of these effects (Table 1). As many aroma compounds are lipophilic, they are stored in and released from the fat phase of a matrix during eating (Kinsella 1989). The reduction and, in particular, the omission of fat from foods therefore results in a changed aroma and flavor profile. Recent studies on polar (e.g. diacetyl) and nonpolar (e.g. linalool) aroma compounds in emulsions varying in fat content from 10 to $60 \%$ demonstrate the different aroma release based on solubility properties (Hyvönen et al. 1997) (Fig. 1).
Interaction of fat with other components was demonstrated with strawberry yogurts (Tuorila et al. 1993). Fat content of the yogurts varied from 0 to $5 \%$ and sucrose content from 6 to $12 \%$ $(4 \times 4$ factorial design). The perceived fattiness of the yogurts depended on the fat content and on sucrose. Thus, the lowest level of sucrose resulted in low ratings of fattiness, regardless of the actual fat level. Similarly, sweetness was perceived strongest at the highest fat level. Thus, fat and sucrose mutually enhanced the salient effect of the other. 
Tuorila, H.Consumer perceptions and acceptance of nutritionally modified foods

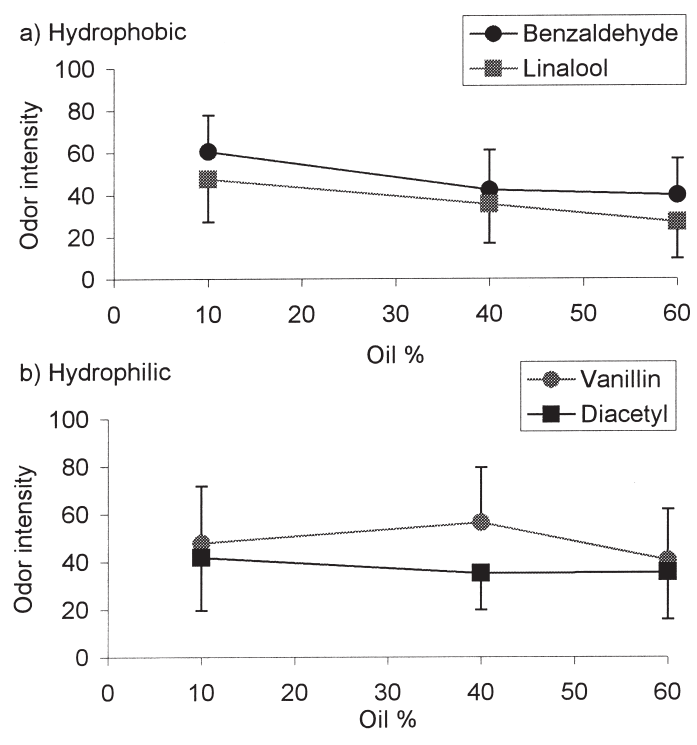

Fig. 1. Odor intensity of polar and nonpolar chemical compounds in emulsions containing $10-60 \%$ vegetable fat (Hyvönen et al. 1997).

The effect of dairy fat (3-12\%, 3 levels) on intensities of sensory attributes of cheese soup was studied at three temperatures from lukewarm $\left(33^{\circ} \mathrm{C}\right)$ to hot $\left(63^{\circ} \mathrm{C}\right)$ (Kähkönen et al. 1995). Fat significantly enhanced all sensory attributes studied, including fattiness and thickness in the mouth, thickness by spoon, cheese odor, cheese flavor, overall odor and flavor and saltiness. Most of the effects can be straightforwardly interpreted as a direct outcome of an increase in fat content. However, the enhancement of perceived saltiness by increasing fat may possibly derive from a decrease in the water phase in the system and thus more concentrated salty water in the sample. Another, perhaps complementary interpretation is the presence of a halo effect, i.e., the tendency of the generally stronger character of a sample to lead to a stronger perception of an individual attribute (Lawless and Heymann 1998).

Along with sensory characterization, hedonic responses to yogurt and cheese soup were studied by relatively small consumer panels.
The lowest fat and sucrose levels in yogurt were not well liked (Tuorila et al. 1993). Male subjects indicated increasing liking for yogurt with increasing concentrations of fat and sucrose while female subjects, as a group, did not show any definite tendency in this direction. The pleasantness of cheese soup increased with increasing fat and increasing temperature, but an interaction was also observed: fat affected favorably only at the two higher temperatures while at the lowest temperature $\left(33^{\circ} \mathrm{C}\right)$, pleasantness ratings were unaffected by the level of fat (Fig. 2) (Kähkönen et al. 1995). This finding demonstrates the importance of interplay between food components and serving conditions. Thus, fat may improve consumer responses to a food, but its favorable effect depends on conditions.

The possibilities of replacing fat with nutritionally more desirable components have been studied, but the success has been limited or product specific, or both. In a study on high-fat (75\% fat) confectionery, $10-20 \%$ of the cocoa fat was replaced by either microcrystalline cellulose or guar gum, or their combination (Lawless et al. 1996). With increasing fat content, the perceived sweetness and melting rate in the mouth decreased while the viscosity of the mass, hardness, adhesiveness, and particles in the mouth were increased. Guar gum tended to have greater sensory effects than the microcrystalline cellulose. This example shows that numerous problems are faced when reducing fat from foods. In addition to texture, flavor is affected.

\section{Sensory and hedonic effects of sodium chloride}

Bakery products are one of the major sources of sodium in Western diets. The omission of sodium chloride leads to a cardboard-like (Salovaara et al. 1982) and crumbly (Salovaara et al. 
Vol. 9 (2000): 165-176.

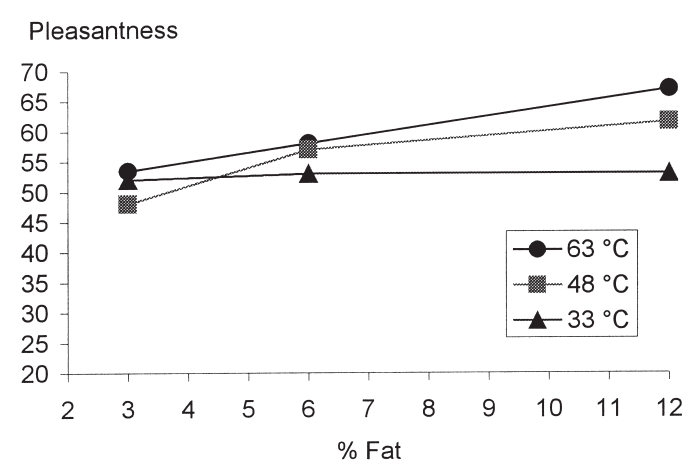

Fig. 2. Pleasantness of cheese soup varying in fat content $\left(3-12 \%\right.$ dairy fat) and temperature $\left(33-63^{\circ} \mathrm{C}\right)$ (Kähkönen et al. 1995).

1986) product with a dry mouthfeel (Tuorila et al. 1990b). In the latter study, the absence of salt from bread was a major negative predictor for the acceptance of a sandwich that also contained full- or reduced-fat cheese and was either spread with margarine or without spread. Partial reduction of salt from bread causes considerably less sensory loss than its total omission. Particularly in rye bread, increasing concentrations of acetic and lactic acids contribute to increasing saltiness, and thus significantly compensate for salt (Hellemann 1992).

A complex food system contains many ingredients and thus, enables many interactions among components. A recent experiment on bread was designed to simultaneously examine the effects of salt, acid and ash contents (ash content reflects the degree to which outer parts of the kernel are present in flour) on sensory intensities and consumer responses. The acceptance and the extent to which sour rye bread and crispbread met consumer expectations were predicted from these factors (Heiniö et al. 1997). The acidity level and ash content were much more critical for meeting consumer expectations than was the salt content. The analysis of the contribution of various experimental factors on perceived saltiness showed that saltiness was affected both by $\mathrm{NaCl}$ content and acidity, but not by ash content, thus confirming earlier findings by Hellemann (1992). Fig. 3 illustrates these relationships. E.g., a similar saltiness intensity (e.g. 5.0) was perceived in several combinations of acidity and $\mathrm{NaCl}$ content. At a high acidity level, a relatively low $\mathrm{NaCl}$ content was needed while at a low acidity level, a higher $\mathrm{NaCl}$ content was needed to achieve a similar saltiness intensity.

The observation that consumer responses to foods may not necessarily be guided or distracted by variations in a single component, such as salt, was also made using mashed potato as a model food. Sensory difference threshold (the just-noticeable-difference, the smallest perceivable difference) for sodium chloride was found to be $\pm 0.07 \% \mathrm{NaCl}$ when the reference sample contained $0.6 \% \mathrm{NaCl}$ (Laurila et al. 1996). However, a significant change in pleasantness ratings of mashed potato required a deviation of $\pm 0.2-0.3 \%$ from the reference $(0.6 \%$ $\mathrm{NaCl}$ ).

The replacement of $\mathrm{NaCl}$ by other flavorings was studied by asking subjects to mix to optimal saltiness, by tasting and retasting, from each of the four pairs of unsalted and heavily salted beef broths (Tuorila et al. 1990a). Each pair was flavored with a different combination of spices and flavors (marjoram, onion, allspice, monosodium glutamate), and the sodium content of each resulting mixture was determined using chemical analyses. In the presence of spices and flavorings, the sodium levels of the mixtures were expected to be lower than in their absence. The chemical analyses indicated identical sodium contents, regardless of the flavor combination. However, the added flavorings contributed to the rated pleasantness of the mixtures. Obviously, saltiness is difficult to achieve with substances other than $\mathrm{NaCl}$, but the overall pleasantness of a reduced-salt product can be enhanced by other substances.

Further evidence for this finding was obtained in a study in which, over five weeks, subjects repeatedly consumed and rated low-salt 


\section{AGRICULTURAL AND FOOD SCIENCE IN FINLAND}

Tuorila, H.Consumer perceptions and acceptance of nutritionally modified foods
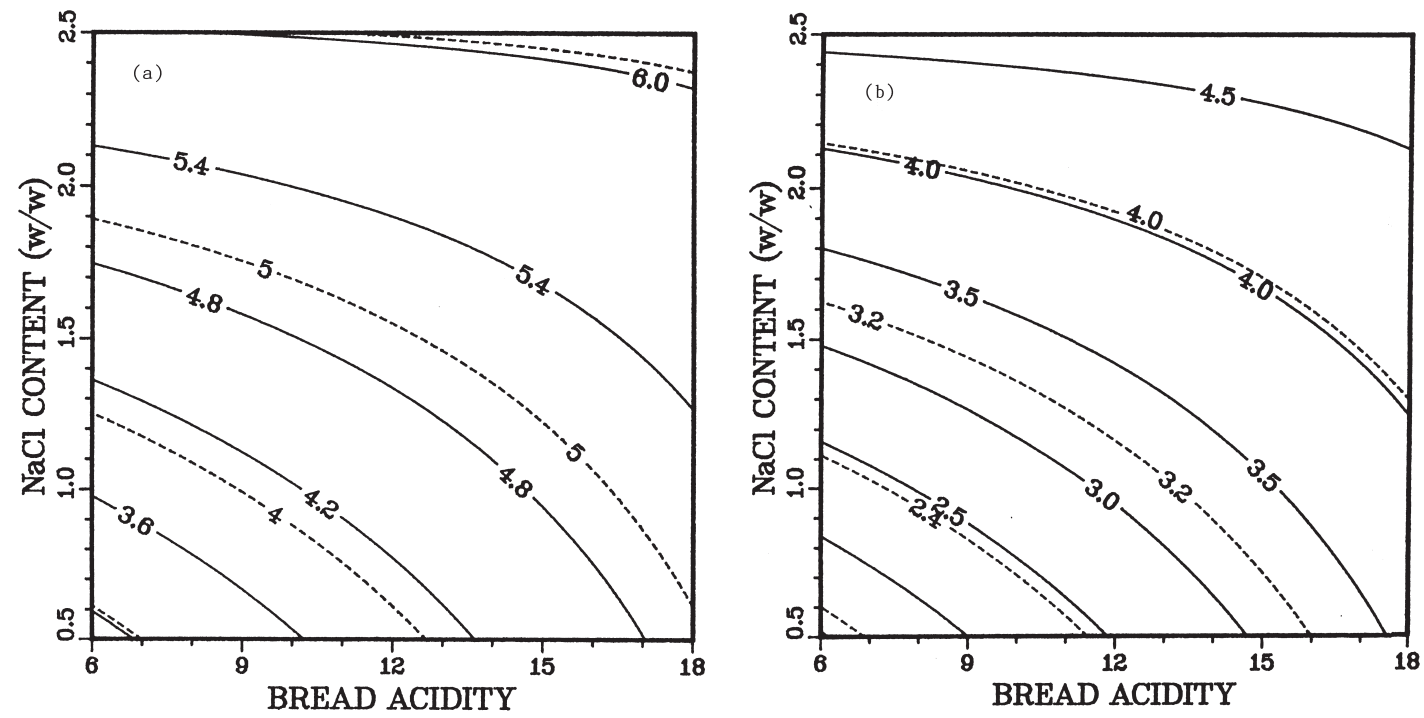

Fig.3. Perceived saltiness of sour rye bread (a) and crispbread (b) as a function of ash content, bread acidity and $\mathrm{NaCl}$ content (ash content $0.7 \%=$ $1.8 \%=$ - ). The saltiness intensity was rated from 1 (not at all salty) to 9 (very salty), and the contour lines describe the level of saltiness rating achieved at a certain combination of $\mathrm{NaCl}$ and acidity (Heiniö et al. 1997).

soups that either contained umami substances (monosodium glutamate and ribonucleotides) or did not (Roininen et al. 1996). The presence of umami substances helped to maintain a liking for the low-salt samples for this extended period of testing. The amount of sodium derived from monosodium glutamate was so low that it did not directly increase saltiness of umami containing soups.

\section{Effects of information on consumer perception and acceptance}

Product information is an important part of marketing and consumer education, and thus it is important to analyze effects of nutritional or health claims on consumer perceptions. Various product and consumer based information effects have been found in recent studies. In the case of well-liked products, such as currently marketed fat-free yogurts, the information on fat content did not affect the rated pleasantness (Kähkönen et al. 1997). On the contrary, a less liked product such as a reduced-fat ( $40 \%$ vegetable fat), reduced-salt $(0.7 \% \mathrm{NaCl})$ table spread was rated higher if the nutritional facts were available (Kähkönen et al. 1996), compared to ratings in a blind test. This favorable effect was further intensified if the consumers were generally concerned about their health and nutrition. Once the information was delivered, its effect lasted over a home use period of one week. Thus, nutritional information appears to be in a crucial position in the efforts to improve consumer responses to nutritionally favorable, but less preferred products. 
Vol. 9 (2000): 165-176.

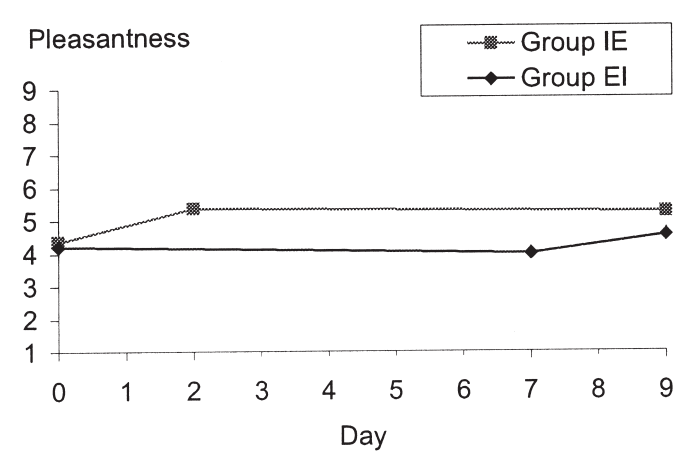

Fig. 4. Effect of nutritional information on the pleasantness of a spread. On Day 0, all subjects rated the spread blind. With information available, the Group IE (information prior to exposures) rated the spread on Day 2 and then used this spread at home on Days 2-9. Group EI (exposures prior to information) used the spread blind on Days $0-7$, then rated the spread blind. On Day 9, both groups had the information available during the rating (Kähkönen et al. 1996).

The timing of information delivery may be critical (Kähkönen et al. 1996). One group of subjects (Group EI =exposures prior to information) used the spread at home without being informed of the nutritional information. The other group (Group IE = information prior to exposures) had the information available during home use (Fig. 4). When the former group received the information after home use, the hedonic ratings were not higher than before home use. Thus, the exposure period stabilized the pleasantness ratings, thus perhaps preventing a change even though new nutritional information became available. If confirmed in other studies, this finding means that information has the highest potential for impact at early stages of product launching or exposure to a new product.

The effect of information was also examined in a recent study on a fermented oat bran product 'yosa' - a new snack product that resembles flavored yogurt or porridge (Tuorila et al. 1998). Two distinctly different age groups, 15-year-old boys and girls and elderly subjects (mean age 77 years) were presented with yosa in two infor- mation groups: half of the age group was told that the product was 'low-calorie, nutritionally wholesome' while the other half was told that the product was 'high-fiber, containing stomach-friendly lactic acid bacteria'. In general, the elderly responded to the product (an experimental version of 'yosa', tested prior to launching the product onto the Finnish market) much more favorably than the young (Fig. 5). The information had no effect on the 15-yearsold - not even the low-calorie information on the girls. On the contrary, among the elderly the information on high fiber content increased the purchase interest and the willingness to recommend the product to friends. According to questionnaire data, the elderly were very concerned about their fiber intake. Thus, in order to have an impact the information must be relevant to the consumer. Information may affect behavior (choices) even if pleasantness ratings remain unaffected.

\section{Dietary changes and pleasantness shifts}

Certain diseases or health concerns cause a need for a special diet. Research on British consumers suggests that the difficulties to adhere to a reduced-fat diet mainly derive from negative experiences on sensory properties of reducedfat foods (Lloyd et al. 1995). North American consumers persistently expected fat-free foods to be less pleasant than the regular-fat foods (Tuorila et al. 1994). Thus, the adoption of the new dietary habits may turn out to be difficult if 'healthful' foods are expected to be - or in fact are - disappointing in terms of taste.

Yet there are encouraging examples of food categories in which the shift to the reduced-fat and fat-free options has been successful and apparently causes no losses after an adjustment period. For example, a large proportion of Finnish consumers currently drink nonfat milk, and re- 


\section{AGRICULTURAL AND FOOD SCIENCE IN FINLAND}

Tuorila, H.Consumer perceptions and acceptance of nutritionally modified foods
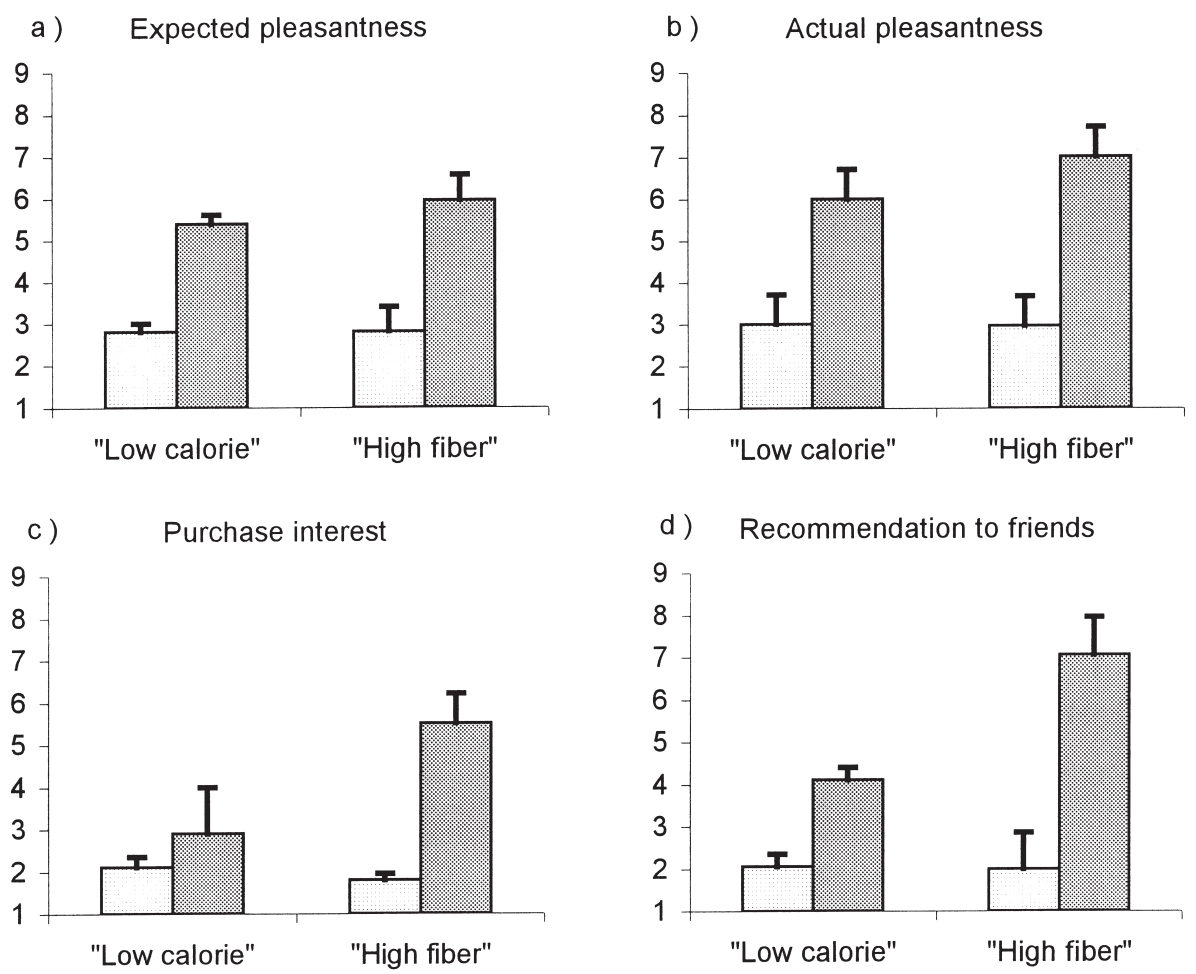

d) Recommendation to friends

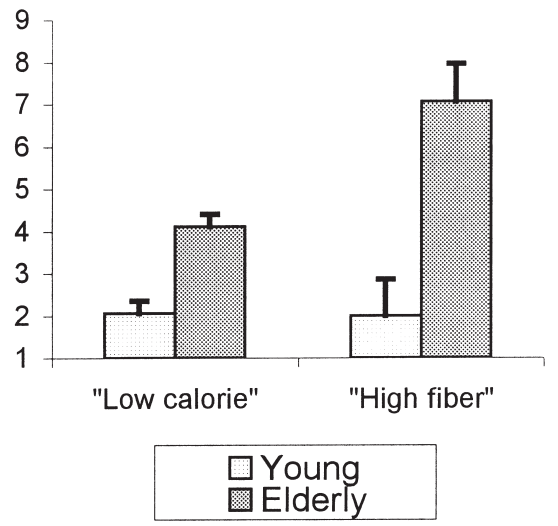

Fig. 5. Ratings of yosa among young (15-year-olds) and elderly subjects in two information conditions ('low-calorie' and 'high-fiber'). a) Expected pleasantness based on appearance, b) actual pleasantness based on tasting, c) purchase interest after tasting and d) likelihood of recommendation to friends after tasting. Data from Tuorila et al. (1998).

search has shown that individual consumers prefer the fat level in milk that they are used to (Tuorila 1987). Thus, no frustration or deprivation needs to be associated with a changed consumption regimen.

Northern American studies show that adopting a reduced-salt diet requires 2-3 months (Blais et al. 1986, Bertino et al. 1982). A similar learning period has been suggested for fat but the scientific evidence is not equally convincing (Mattes 1993). Studies in which consumer groups have been exposed to certain reduced-fat (vs. regular-fat) foods do not indicate that the exposure would enhance the acceptance of reduced-fat cheese and chips (Mela et al. 1993) or chocolate (Holopainen 1998).

Liking for sweet and fatty foods among newly diagnosed diabetics was examined over three months using questionnaires and sensory tests (Laitinen et al. 1991). During the first six weeks, subjects reported enhanced liking for reduced-fat and high-fiber foods and decreased liking for high-fat and high-sugar foods. The survey results may have been affected by social desirability bias whereby subjects may try to respond in the way they think is appropriate, 
Vol. 9 (2000): 165-176.

rather than giving their true opinion. However, the patients of this study lost weight and their metabolic control improved during the three months. This supports the view that they were probably highly motivated and thus, truly accepted the change or their eating patterns.

Some evidence for the correlation between the hormonal status and fat preferences was obtained in a recent study, in which obese women evaluated various sweet and/or fatty stimuli. A lowered preference for some high-fat items was found to be related to high serum leptin concentration (Karhunen et al. 1998). The finding is consistent with the view that high leptin levels reflect satiety. If the association between leptin levels and fat preferences is established in further research, this will lead to a better understanding of the relationship between physiological status and hedonic responses to foods.

Among dieters, ratings of liking, desired use and reported use of various fatty and sweet foods were related to their cognitive restraint, disinhibition and hunger (Lähteenmäki and Tuorila 1995). The latter three factors were measured using a special questionnaire developed for the quantification of these features (Stunkard and Messick 1985). Liking and use of high-fat and high-sugar foods was found to be characteristic of those subjects whose emotional (disinhibition) and physiological (feelings of hunger) responses were high. Desired use frequencies of high-fat, high-sugar foods were generally higher than the reported current use frequencies. Obviously, the emotional emphasis on food and eating, as well as an inability to control hunger, can break an individual's diet, because the desire for certain foods becomes imperative and irresistible.

Foods have varying degrees of importance for individual consumers. One way of describing these differences is through the involvement with the products. Consumers rated their liking for regular- and reduced-fat chocolate bars, yogurts, margarines and frankfurters, and they also filled out a questionnaire on their involvement with each type of product (Kähkönen and
Tuorila 1999). The high involvement with frankfurter or with a chocolate bar led to low pleasantness and purchase interest in the reduced-fat versions. Thus, if a product is important for a consumer (if s/he is highly involved with it), accepting its reduced-fat or fatfree version may be particularly difficult. Consequently, when individuals are put on special diets they should be encouraged to search for alternative foods so that the feelings of loss and deprivation are minimized.

\section{New instruments to measure consumer orientations to foods}

When food supply is abundant, consumers appear to be segment-based in their food orientations. Verbal instruments are being developed and validated to quantify individual health and pleasure related tendencies (Roininen et al. 1999). The instruments consist of six verbal subscales, each including 6-8 statements to be rated on a Likert scale from 'disagree' to 'agree'. For example, the subscale on General health interest contains a statement 'I am very particular about the healthfulness of my diet' and the subscale on Craving for sweet foods has an item 'I often crave for sweets'. The items have been translated into English, Dutch, Norwegian and Swedish, and have been tested in different European countries (Roininen et al. 2000). A validation trial of the scales (a group of consumers choosing either an apple or a chocolate bar as their snack) suggests a promising predictive ability (Roininen and Tuorila 1999). For example, the extent to which a person has a general health interest or craving for sweet foods strongly affected whether s/he chose an apple or chocolate bar as an afternoon snack (Fig. 6). In the future, these instruments can hopefully be used for tracking trends among various consumer groups over longer periods of time, so that health and pleasure oriented changes could be more accurately predicted. 
Tuorila, H.Consumer perceptions and acceptance of nutritionally modified foods
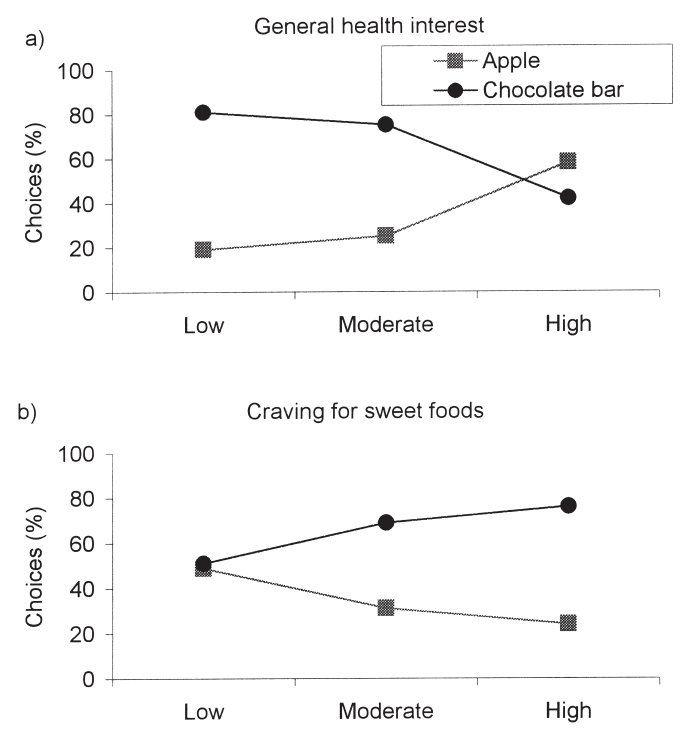

Fig. 6. Choice of an apple vs. a chocolate bar for an afternoon snack among subjects who were divided into tertiles (low, moderate and high) on attitude scales quantifying their a) General health interest and b) Craving for sweet foods (Roininen and Tuorila 1999).

\section{Conclusions}

In Finland, the diet related health risks at the population level and, consequently, the high public awareness of diet - health connections have promoted development, research and consumption of nutritionally modified foods. Research on consumer responses to such foods is capable of revealing trends and effects while the actual tailoring of modified products remains the task of industry.

Consumer interest in nutritionally modified foods, in particular in functional foods, is expected to continue increasing. Long-term acceptance of 'healthful' products among consumers is necessary to make their manufacture worthwhile, and identification of sensory and hedonic barriers to the acceptance of these foods is important for targeting product development and nutritional counseling. Consumer research is also needed to determine the conditions under which perceived health benefits can help to maintain the long-term popularity of such products.

\section{References}

Bertino, M., Beauchamp, G.K. \& Engelman, K. 1982. Long-term reduction in dietary sodium alters the taste of salt. American Journal of Clinical Nutrition 36: 1134-1144.

Blais, C.A., Pangborn, R.M., Borhani, N.O., Ferrell, M.F., Prineas, R.J. \& Laing, B.1986. Effect of dietary sodium restriction on taste responses to sodium chloride: a longitudinal study. American Journal of Clinical Nutrition 44: 32-43.

Heiniö, R-L., Urala, N., Vainionpää, J., Poutanen, K. \& Tuorila, H. 1997. Identity and overall acceptance of two types of sour rye breads. International Journal of Food Science and Technology 32: 169-178.

Hellemann, U. 1992. Perceived taste of $\mathrm{NaCl}$ and acid mixtures in water and bread. International Journal of Food Science and Technology 27: 201-211.

Hogbin, G. \& Fulton, L. 1992. Eating quality of biscuits and pastry prepared at reduced fat levels. Journal of the American Dietetic Association 92: 993-995.

Holopainen, N. 1998. Effects of exposure and attitudinal background on consumer acceptance of reducedfat and full-fat chocolate. MSc thesis, University of Helsinki, Department of Technology, EKT-series no. 1136. Helsinki (in Finnish, summary in English).

Hyvönen, L., Kilpi, M., Eskola, M. \& Tuorila, H. 1997. Odour and flavour release from emulsions of varying fat content. In: 19th Nordic Lipid Symposium. Proceedings. Lipidforum, Bergen. p. 109-114.

Kähkönen, P. \& Tuorila, H. 1999. Consumer responses to reduced and regular fat content in different products: effects of gender, involvement and health concern. Food Quality and Preference 10: 83-91.

- , Tuorila, H. \& Lawless, H. 1997. Lack of effect of taste and nutrition claims on sensory and hedonic responses to a fat-free yogurt. Food Quality and Preference 8: 125-130. 
Vol. 9 (2000): 165-176.

- , Tuorila, H. \& Hyvönen, L. 1995. Dairy fat content and serving temperature as determinants of sensory and hedonic characteristics in cheese soup. Food Quality and Preference 6: 127-133.

- , Tuorila, H. \& Rita, H. 1996. How information enhances the acceptability of a low-fat spread. Food Quality and Preference 7: 87-94.

Karhunen, L.J., Lappalainen, R.I., Haffner, S.M., Valve, R.H., Tuorila, H., Miettinen, H. \& Uusitupa, M.I.J. 1998. Serum leptin, food intake and preferences for sugar and fat in obese women. International Journal of Obesity 22: 819-821.

Kinsella, J.E. 1989. Flavor perception and binding to food components. In: Min, D.B. \& Smouse, T.H. (eds.) Flavor Chemistry of Lipid Foods. American Oil Chemist Society, Illinois. p. 376-403.

Koivisto Hursti, U.K. 1997. Child food choice and the family. Comprehensive Summaries of Uppsala Dissertations from the Faculty of Medicine 671. Acta Universitatis Upsaliensis.

Lähteenmäki, L. \& Tuorila, H. 1994. Attitudes towards sweetness as predictors of liking and use of various sweet foods. Ecology of Food and Nutrition 31: 161-170.

- \& Tuorila, H. 1995. Three-factor eating questionnaire (TFEQ) and the use and liking of sweet and fat among dieters. Physiology \& Behavior 57: 81-88.

Laitinen, J. H., Tuorila, H.M. \& Uusitupa, M.I.J. 1991. Changes in hedonic responses to sweet and fat in recently diagnosed non-insulin-dependent diabetic patients during diet therapy. European Journal of Clinical Nutrition 45: 393-400.

Laurila, E., Lähteenmäki, L., Rita, H. \& Tuorila, H. 1996. Pleasantness in relation to difference threshold of $\mathrm{NaCl}$ in mashed potato. Food Quality and Preference 7: 225-228.

Lawless, H.L. \& Heymann, H. 1998. Sensory evaluation of food: Principles and practices. Chapman \& Hall, New York.

Lawless, H.T., Tuorila, H., Jouppila, K., Virtanen, P. \& Horne, J. 1996. Effects of guar gum and microcrystalline cellulose on sensory and thermal properties of a high fat model system. Journal of Texture Studies 27: 493-516.

Lloyd, H.M., Paisley, C.M. \& Mela, D.J. 1995. Barriers to the adoption of reduced fat diets in a UK population. Journal of the American Dietetic Association 95: 316-322.

Mattes, R. 1993. Fat preference and adherence to a reduced-fat diet. American Journal of Clinical Nutrition 57: 373-381.

- 1996. Determinants of dietary fat intake in humans. In: MacDonald, R.E. \& Min, D.B. (eds.) Food Lipids and Health. Marcel Dekker, New York. p. 437-457.

- 1997. The taste for salt in humans. American Journal of Clinical Nutrition 65(suppl): 692S-697S.

Mela, D.J. \& Raats, M.M. 1995. Role of fat in the consumer acceptance of dairy products. In: Fox, P.F. (ed.) Advanced Dairy Chemistry, Volume 2: Lipids. Chapman \& Hall, London. p. 403-432.
- , Trunck, F. \& Aaron, J.I. 1993. No effect of extended home use on liking for sensory characteristics of reduced-fat foods. Appetite 21: 117-129.

Roininen, M.K., Lähteenmäki, L. \& Tuorila, H. 1996. Effect of umami taste on pleasantness of low-salt soups during repeated testing. Physiology \& Behavior 60: 953-958.

- , Lähteenmäki, L. \& Tuorila, H. 1999. Quantification of consumer attitudes to health and hedonic characteristics of foods. Appetite 10: 71-88.

- \& Tuorila, H. 1999. Health and taste attitudes in the prediction of use frequency and choice between less healthy and more healthy snacks. Food Quality and Preference 10: 357-365.

- , Tuorila, H., Zandstra, E.H., De Graaf, C., Stubenitsky, K. \& Mela, D. Cross-cultural validation of the "Health and Taste Attitude Scales" (HTAS). Abstract, the 7th Nordic Nutrition Congress, Mariehamn, June 18-21, 2000.

Salovaara, H., Hellemann, U. \& Kurkela, R. 1982. Effect of salt on bread flavour. Lebensmittel- Wissenschaft und Technologie 15: 270-274.

- , Hyöppönen, R-L., Raevuori, M. \& Kauppinen, V. 1986. Effect of sodium chloride levels on ageing of wheat and sour rye bread. Lebensmittel-Wissenschaft und Technologie 19: 376-381.

Shepherd, R. 1988. Sensory influences on salt, sugar and fat intake. Nutrition Research Reviews 1: $125-144$.

- 1989.Factors influencing food preferences and choice. In: Shepherd, R. (ed) Handbook of Psychophysiology of Human Eating. Wiley, Chichester. p. 3-24.

Stunkard, A.J. \& Messick, S. 1985. The three-factor eating questionnaire to measure dietary restraint. Journal of Psychosomatic Research 29: 71-83.

Troutt, E.S., Hunt, M.C., Johnson, D.E., Claus, J.R., Kastner, C.L., Kropf, D.H. \& Stroda, S. 1992. Chemical, physical, and sensory characterization of ground beef containing 5 to $30 \%$ fat. Journal of Food Science 57: 25-29.

Truswell, A.S. 1987. Evolution of dietary recommendations, goals, and guidelines. American Journal of Clinical Nutrition 45: 1060-1072.

Tuorila, H. 1986. Sensory profiles of milks with varying fat contents. Lebensmittel-Wissenschaft und Technologie 19: 344-345.

- 1987. Selection of milks with varying fat content and related overall liking, attitudes, norms and intentions. Appetite 8: 1-14.

- , Andersson, Å., Martikainen, A. \& Salovaara, H. 1998. Effect of product formula, information and consumer characteristics on the acceptance of a new snack food. Food Quality and Preference 9: 313-320.

- , Cardello, A.V. \& Lesher, L.L. 1994. Antecedents and consequences of expectations related to fat-free and regular-fat foods. Appetite 23: 247-263.

- , Hellemann, U. \& Matuszewska, I. 1990a. Can sodium contents of foods be reduced by adding fla- 
Tuorila, H.Consumer perceptions and acceptance of nutritionally modified foods

vors? Studies with beef broth. Physiology \& Behavior 47: 709-712.

- , Lehtovaara, A. \& Matuszewska, I. 1990b. Sandwiches and milk with varying fat and sodium contents: what is the best combination? Food Quality and Preference 2: 223-231.

- , Sommardahl, C., Hyvönen, L., Leporanta, K. \& Merimaa, P. 1993. Sensory attributes and acceptance of sucrose and fat in strawberry yoghurts. International Journal of Food Science and Technology 28: 359-369.

Valtion ravitsemusneuvottelukunta. 1998. Suomalaiset ravitsemussuositukset. Komiteanmietintö 7, Edita, Helsinki (Finnish Nutrition Recommendations, available in Finnish and Swedish).

\title{
SELOSTUS
}

\section{Muutospaineet ja muutosvastarinta: kuluttajien suhtautuminen ravitsemuksellisesti muunnettuihin elintarvikkeisiin}

\author{
Hely Tuorila \\ Helsingin yliopisto
}

Mieltymykset ja tottumukset ohjaavat yksilöllisiä ruokavalintoja ja voivat helposti johtaa esimerkiksi rasvan tai ruokasuolan liialliseen käyttöön. Aistinvaraista tutkimusta tarvitaan mitattaessa koostumuksen vaikutusta elintarvikkeiden aistittavaan laatuun ja hyväksyttävyyteen. Perinteisessä aistinvaraisessa tutkimuksessa määritetään tuotteen aistittavia ominaisuuksia koulutetun raadin avulla, hyväksyttävyystutkimuksessa etsitään tuotteen suosion tai kelpaamattomuuden syitä tuotteen lisäksi kuluttajasta ja tilanteesta.

Rasvan määrän ja laadun vaihtelu havaitaan elintarvikkeen rakenteessa. Rasvasisällön muutos vaikuttaa myös tuotteen aromiin ja makuun. Rasvan ja ruokasuolan korvaaminen muilla aineilla ei ole helppoa, mutta esim. maustamalla voi korjata suolan vähentämisestä johtuvaa miellyttävyyden vähenemistä.

Useimpien aineosien määrällä elintarvikkeessa on kullakin oma aistinvarainen optiminsa, jolloin tuotteen aistittava laatu vastaa kuluttajan aikaisempiin kokemuksiin pohjautuvia odotuksia. Yhden valmistusaineen pienehköt muutokset eivät kuitenkaan välttämättä vaikuta tuotteen hyväksyttävyyteen. Tuotteen ravintosisällöstä annettu tieto voi vaikuttaa suotuisasti etenkin uuden tuotteen vastaanottoon. Tiedon vaikuttavuus vaihtelee tuotteen ja yksilön mukaan, ja mm. kuluttajan terveystietoisuus edistää tiedon vaikutusta. 